\title{
Tropical Malady: Film \& the Question of the Uncanny Human-Animal
}

\author{
"The tiger trails you like a shadow/ his spirit is starving and lonesome/I see \\ you are his prey and his companion” - Tropical Malady.
}

\section{Barbara Creed}

\author{
University of Melbourne
}

\begin{abstract}
The acclaimed Thai film, Tropical Malady (2004), represents the tropics as a surreal place where conscious and unconscious are as inextricably entwined. Directed by Apichatpong Weerasethakul, Tropical Malady presents two interconnected stories: one a quirky gay love story; the other a strange disconnected narrative about a shape-shifting shaman, a man-beast and a ghostly tiger. This paper will argue that from it beginnings in the silent period, the cinema has created an uncanny zone of tropicality where human and animal merge.
\end{abstract}

$\mathrm{F}$ rom its beginnings in the early twentieth century the cinema has expressed an enduring fascination with the tropics as an imaginary space. While many filmmakers have envisaged the tropics as an unspoiled paradise (Bird of Paradise, 1932, 1951; The Moon of Manakoora, 1943; South Pacific, 1958), a view which has its origins in classical times, others have represented the tropics as a deeply uncanny zone where familiar and unfamiliar coalesce. It is as if the heat and intensity of the tropics has liquefied matter until normally incommensurate forms are able to dissolve almost imperceptibly into each other. In this process the boundaries between different systems of thought, ideas and ethics similarly dissipate, creating a space for new and often subversive ideas to flourish. As Driver and Martins state, the meaning of "tropicality" is so elastic a number of discourses have been able to shape it to suit their own purposes. "At different moments, in different contexts, the notion of tropicality has been enrolled in a variety of philosophical, political, scientific, and aesthetic projects”. (Driver \& Martins 3) The visual arts are no exception. Henri Rousseau's idyllic jungle canvases and Max Ernst's surreal Joie de Vivre landscapes of forests in Indochina offer very different interpretations of tropicality.

The cinema's major themes of tropicality involve fantasies of a sexual sublime in which human passion is given free rein (Siren of the Tropics, 1927; Rain, 1932; Blonde Venus, 1933; From Here to Eternity, 1953; The Beach, 2000) and evolutionary fantasies of degeneration in which the fragile line dividing between civilization and nature, human and animal is ruptured (Island of Lost Souls, 1932; I Walked with the Zombie, 1943; King Kong 1933, 2005; Apocalypse Now, 1979). The cinematic tropics offer an imaginative 
space in which we are free to recreate, to explore anew the beginnings of human history and desire, but almost always from a disturbing and uncanny perspective. In many of these films, the tropical setting pulls in opposite but inter-related directions: it is luxuriant and abundant, nightmarish and frightening. Charles Darwin's famous description of life's tangled bank could equally apply to the way in which writers have imagined the darker dimensions of a tropical rainforest. "It is interesting to contemplate an entangled bank, clothed with many plants of many kinds, with birds singing on the bushes, with various insects flitting about, and with worms crawling through the damp earth". (Darwin, 2003, 913)

This paper will explore the uncanny nature of the cinematic tropical zone, specifically in relation to the theme of the merging of human and animal. The appearance of the awardwinning Thai film, Tropical Malady (Sud Pralad) in 2004 with its focus on desire, death and the human/animal nexus continues this tradition, but with an unexpected focus on shamanism and human/animal desire as signifying a strange sickness of the soul, a form of tropical malady.

Although the revolutionary theories of Charles Darwin may seem remote from the interests of early cinema, and tropicality, there is an unexpected connection. Darwin's ideas influenced a number of fin de siècle authors whose works were adapted for the screen. I am thinking of four in particular: H. G. Wells, Sir Arthur Conan Doyle, Edgar Rice Burroughs and Edgar Wallace. ${ }^{1}$ These authors were responsible for a series of works, which explored concepts of evolution and devolution, anthropocentrism, and the human/animal nexus. They set their imaginative narratives in tropical zones. These included H.G. Wells' The Island of Doctor Moreau (1896), Conan Doyle's The Lost World (1912), and Edgar Rice Burrough's Tarzan of the Apes (1914). The writings of Conan Doyle and Edgar Wallace, along with Merian C Cooper, led to the creation of the classic film, King Kong (1933), also set on a tropical island, known ominously to sailors as Skull Island. Common to these novels, and film adaptations, was the evolutionary theme of the fragile line between human and animal. Although Darwin did not promote the concepts of degeneration, survival of the fittest, bestiality or human/animal hybrids, his theory of evolution stimulated writers to explore these related, and often darker, possibilities.

Over the decades the cinematic adaptations of these classic texts have proven so popular they have led to the emergence of new sub-genres. These include the King Kong series and its classic remakes and offshoots; the numerous versions of H.G. Wells' influential novel, The Island of Doctor Moreau; and the ever-popular, Tarzan of the Apes sub-genre of jungle films. The Tarzan genre has been so successful it has generated over 50 titles stretching from 1918-2001. Significantly, the setting or location for these iconic texts is the tropics. The philosophical project which appears to have influenced all of these authors is a questioning of the anthropocentric view of life which Darwin himself questioned - that is the position which places the human species at the centre of all things, as the source or origin of all that is significant and worthwhile. Darwin's belief that "all animals and plants have descended from some one prototype ... from some one

\footnotetext{
${ }^{1}$ For a fuller discussion see Creed, Barbara. Darwin’s Screens.
} 
primordial form” (2003: 909) finally undermined what had been a relatively fixed boundary between human and animal. The idea that humankind was one animal species among many challenged a belief in the singularity of the human species. According to Gillian Beer in Darwin's universe "there was no crucial explanatory function for God, nor indeed was there any special place assigned to the human in his argument”. (Beer xviii) Margot Norris supports Beer's view. "God is abolished along with the fiction of the subject as the origin of the text". (Norris 26) What we find in these tropical narratives is that God is replaced by a deranged scientist (Doctor Moreau) whose strange creatures are more empathetic, a sympathetic beast (King Kong) and an ape-man who lives in harmony with the natural world (Tarzan). The boundaries between human and animal blur sufficiently to bring into question the meaning of "human".

\section{(i) The Uncanny tropical zone}

The principles, which regulate the narratives of these texts, are those of uncertainty, change and disorientation. The often-foreboding atmosphere is accompanied by a strange sense of dread or uncanniness, a concept, which has much to offer to a full comprehension of the tropical imaginary. In his discussion of the uncanny, Freud wrote that the key to understanding the concept is the relationship of the familiar to the unfamiliar:

The German word "unheimlich" is obviously the opposite of "heimlich" ["homely"], "heimisch" ["native"] — the opposite of what is familiar; and we are tempted to conclude what is "uncanny" is frightening precisely because it is not known and familiar ... Something has to be added to what is novel and unfamiliar in order to make it uncanny. (Freud 341)

Freud was particularly interested in the "home" as a site for the emergence of the uncanny. The "heimlich" is potentially that which is known, familiar and comforting; its opposite, the "unheimlich" gives rise to that which is unknown, unfamiliar, even frightening. Ultimately the uncanny is that which should have remained hidden, out of sight. As Rosemary Jackson states, this way of understanding the uncanny adds an ideological or "counter cultural" edge to the concept. (Jackson 69) The films discussed above represent the tropical imaginary, from the spectator's point of view, as unheimlich, a space that is troubling and difficult to comprehend. Doctor Moreau's island of pain, Tarzan the Ape-Man's idyllic but dangerous jungle, King Kong's pre-historical isle where evolution has stopped still—each of these zones represent the uncanny, disturbing face of the Tropics. They are rendered uncanny because in each the narrative collapses the boundaries between culture and nature, human and animal. The obscure, troubling idea that these films explore and which should have remained hidden, is humanity's relationship to the animal, that is, humanity's own animal origins. Is humanity's uncanny other/double the animal?

Another writer who explored this possibility, and who was also influenced by Darwin's theory of evolution, was Robert Louis Stevenson. In 1886, Stevenson wrote The Strange Case of Dr Jekyll and Mr Hyde, which proved to be a sensation, selling over 250,000 
copies by 1901. Adapted for the stage and later into many film versions, Dr Jekyll and Mr Hyde represents a respectable Victorian doctor who invents a strange potion that transforms him into a beast. "I learned to recognize the thorough and primitive duality of man". (79) It is this duality that is central to the tropical narratives, and their unique characteristics.

\section{(ii) Tropical Vision - blurred sight}

Of all the films mentioned above, The Island of Lost Souls represents the most bizarre exploration of humankind's desire to reunite human and animal. Based on H.G. Wells' tale of horror, The Island of Dr Moreau, the film features a Frankensteinian scientist, Dr Moreau, who lives on a remote tropical island where is attempting to create human forms from the animal through the cruel practice of vivesection. His experiments are all doomed to failure as the human cannot withstand the onslaught of the animal and the "stubborn beast flesh" grows back in every instance (Wells 113). When the hero, a shipwrecked sailor named Edward Parker first sets eyes upon the beast-people he cannot believe his eyes. He finds them strange and uncanny. Although human in form they bear "the unmistakeable mark of the beast". (Wells 40) They conveyed "two inconsistent and conflicting impressions of utter strangeness and yet of the strangest familiarity". (Wells 40)

Both the novel and the film emphasise how the tropical jungle and its tangle of creepers and thick undergrowth make it difficult to see clearly. In the novel, Parker refers the way in which the tropics have affected the way he sees things.

Then, looking hard, I distinguished through the interlacing network the head and body of the brute I had seen drinking. He moved his head. There was an emerald flash in his eyes as he glanced at me from the shadow of the trees, a half-luminous colour, that vanished as he turned his head again. He was motionless for a moment, and then with noiseless tread began running through the green confusion. In another moment he had vanished behind some bushes. I could not see him, but I felt that he had stopped and was watching me again. (Wells 41)

Vision in the tropical jungle is partial - marred by the "interlacing network" of creepers, "the shadow of the trees" and "green confusion". By the time Parker first encounters Lota the Panther woman (invented for the film) he is unable to see clearly at all. Parker falls in love with Lota, which delights Moreau who wants her to mate with a human to see what will happen. Moreau's tropical island is represented as a space beyond the borderlines of civilisation, a torrid zone of passion and excess. As in the novel, the film also uses shadows and vines to make vision difficult. Despite the film's arresting aesthetic qualities, it was banned in Britain until 1958 because of its theme of vivisection. The censor's report referred to it as a "monstrosity" (Burt 2002: 134). The censor may also have been responding to the film's perverse eroticism represented in Parker's desire for Lota and the possible merging of human with animal. 
Martins and Driver discuss the impact on adventurers and naturalists when they first encountered the Tropics.

When first setting eyes on tropical nature, philosophical naturalists such as Burchell and Humboldt searched for associations - in literature, poetry, and the visual arts. What Darwin called (in 1832) the "total dissimilarity of a Tropical view" was apprehended through a well-established discourse. Rather than following Burchell's concern with the limits and classification of species, however, Darwin sought evidence of dynamic relations and transformation. (Martins and Driver 74)

Darwin's reference to "total dissimilarity" points to the unfamiliar face of the tropics. Darwin was also overwhelmed by the Tropics in its glory, "its luxuriance exceeds even the language of Humboldt to describe". Yet nothing astonished him more than "the first sight of a savage". (Darwin: 2007, 144) It is the juxtaposition of unfamiliar sights which endows the tropics with the power to shock and astonish, making it such an evocative location for cinematic narratives which set out to explore the uncanny.

\section{(iii) Woman and nature - an animal/erotic space}

A central motif that runs through a number of these torrid cinematic narratives is the alignment of woman with the world of nature. The Creature from the Black Lagoon explores the desire of an amphibious human monster for a female scientist who has ventured into his muddy terrain. The description of the power of the tropics to create a languid dream state in Moby Dick recalls the atmosphere of The Creature from the Black Lagoon.

In the serene weather of the tropics... beneath you...swim the hugest monsters of the sea...the tranced ship indolently rolls; the drowsy trade winds blow... everything resolves you into languor. (Melville 149)

In Blonde Venus (1930) Marlene Deitrich engaged in a bizarre strip tease in which she peels off her gorilla suit as she emerges singing "Hot Voodoo" against a stage backdrop of a tropical jungle complete with a chorus of African female singers. As with Tropical Malady, Blonde Venus explores a tropical imaginary in which desire is aligned with sexual repression.

The 1933 classic King Kong directed by Merian C. Cooper and Ernst B. Schoedsack, offers the most unambiguous exploration of this theme. It represents the desire of King Kong, a giant prehistoric ape, for a white woman. The setting is a tropical island, known as Skull Island, where time has stood still. The island appears to be shrouded in thick clouds, making it difficult for the protagonists and the viewer to see clearly. The great ape's desire is clearly sexual as demonstrated in the famous cave sequence in which Kong takes his terrified captive. He has never seen a creature like this before and he is curious. In the previous sequence the film represented Kong as a terrifying, primitive creature. Here the mood changes dramatically. The film encourages us not only to 
identify with Kong but also to see events from Kong's point of view. As the great Ape holds Ann's limp body aloft in his giant paw, curiosity overwhelms him and he gently peels off her clothing. With his other paw, he puts her torn clothing to his nostrils and sniffs. Ann opens her eyes, looks up at Kong in horror and stifles an urge to scream. The music suddenly creates a romantic atmosphere. In a playful mood, Kong begins to tickle Ann who is now indignant and angry. Kong then tickles her bare skin. Ann struggles to free herself free from Kong's great paw. Kong tickles her again and then sniffs her scent, which lingers on his fingers. This sexually charged interaction is cut short when Kong, hearing a rock fall in the cavern, is forced to halt his play and lumber off to investigate.

Outraged by the erotics of the cave scene, the censors ordered it to be cut from prints shortly after the film's release; it was restored in the eighties. Some did not find it at all sexual. David Hogan, writing in 1986, argued that the scene is not "especially titillating". (Hogan 98) Others presented a quite different response. Shortly after its release, the surrealist critic, Jean Ferry, applauded King Kong for its lyrical, dream-like qualities and its "monstrous eroticism" that is "the monster's unbridled love for the woman, cannibalism, human sacrifice”. (Ferry 107) The scene relies on symbolic references to sexual desire by depicting the erotics of touch and scent - Kong's fur brushing against Ann's skin, Kong sniffing her scent, Kong tickling and grasping her body as she struggles to elude his grasp.

The other important issue of the human/animal relation explored in King Kong, and the other tropical films, is that of the emotions. It soon becomes clear that Kong not only desires Ann, but that he also loves her. Ferry refers to his "unbridled love". In the subsequent remakes of King Kong the great beast's love for Ann is also central. These are John Guillermin's 1976 version, which starred Jessica Lange as the captive heroine; and Peter Jackson's 2005 adaptation with Naomi Watts' in the lead role. Of All three Jackson's places the most emphasis on Kong's love for the girl. In fact, there are virtually no references to sexual desire in Jackson's film. What Jackson's great ape desires most is a companion - someone with whom to share his love of nature (recall the scene where they both watch the sunset for the last time on Skull Island), his feelings and his life. Similarly in the Tarzan films, the ape-man expresses deep empathy for the animals in his jungle kingdom, which the creatures reciprocate. While Doctor Moreau clearly feels nothing for his creatures, Lota the panther woman falls in love with Parker.

Films which have represented the tropical imaginary, in relation to the human/animal, have explored the possibility not only that animals experience emotions but that human and animal empathise and communicate with each other. This theme is also the subject of other texts set in tropical zones such as Gorillas in the Mist (1988), the story of Dian Fossey's shared emotional bond with a family of mountain gorillas, and Greystoke, the Legend of Tarzan, Lord of the Apes (1984) in which Tarzan rejects the civilised human world for that of his animal companions with whom he feels a much deeper, and reciprocated, empathy.

This discussion relates to another area of Darwin's revolutionary theory. In his major study, The Expression of the Emotions in Man and Animals (1872), Darwin argued that 
animals experience the same emotions as the human animal including: fear, anger, shame, jealousy, devotion, love and desire. Darwin believed that that the emotions evolved in human and animal alike. "His purpose was to show, through the study of expression, that humans are not a separate divinely created species". (Ekman xxv) Ekman points out that "the continuity of species is today taken for granted by biologists and nearly all social scientists - but not by the general public" (xxvi) ${ }^{2}$ Darwin's theory of the continuity of species also raises questions about the way in which he deploys anthropomorphism. ${ }^{3}$ From its beginnings in the early twentieth century the cinema has represented animals and their emotions in a range of genres, but particularly in films with evolutionary themes that are set in tropical zones - islands, forests, jungles.

\section{Tropical Malady (2004)}

The award-winning, Tropical Malady explores the theme of human/animal from a completely different perspective. Directed by Apichatpong Weerasethakul, the film is structured in two parts - the first a tender love story between two men with intimations of the presence of shamanism in the everyday; the second a mysterious almost surreal narrative about a soldier lost in the forest where he is haunted by the spirit of a shaman in the form of a tiger, which could also be the spirit of his lost companion, Keng. The "malady" in question could be many things: the deadly tropical illness malaria; sexual desire; love; a madness induced by the merging of man and beast. Various critics have complained about the film's obscure, often impenetrable narrative. Yet these moments are also perfectly in harmony with the film's focus on the uncanny.

Weerasethakul commences Tropical Malady with a quotation from the Japanese novelists, Ton Nakajima:

All of us are by nature wild beasts. Our duty as human beings is to become like trainers who keep their animals in check and even teach them to perform tasks alien to their bestiality.

Tropical Malady sets out to examine the fragile border between human and animal and to imagine what might eventuate if the human fails to keep the animal in "check" and the two entities merge. This is the meaning of his "tropical malady". As the film's opening sequence tells us, the animal's spirit "is starving”, we are his "prey and his companion", the animal seeks retribution and reunion. Weerasethakul returns to this theme throughout Tropical Malady, almost imperceptibly in the first part but directly in the second half where he employs scenes charged with poetic realism.

\footnotetext{
2 Recent scientific findings on the function of mirror neurons in humans and animals indicate that it is possible that both experience empathy and other emotions.

${ }^{3}$ Beer argues that Darwin's use of anthropomorphism is both unavoidable and strategic. Ch 2.
} 
The conventional meaning of malady, a disease or disorder of the animal body, does not at first seem at all relevant to the young men. Part one presents a new romance between a soldier named Keng (Banlop Lomnoi) and a rural villager, Tong (Sakda Kaewbuadee) who lives with his family close to a forest. Keng has been assigned to investigate the unusual killings of cattle in the district. Strange happenings offer intimations of the eerie uncanny events to come and when the boundary man and beast begins to erode. There is a scene of soldiers having their photograph taken over the corpse, a naked man walking down a country road, a dinner conversation about the way a spirit departs from a dead body, and rumours about a shaman who has the power to transform himself into a beast.

Keng and Tong meet; Keng is clearly attracted to the younger man and begins to court him. At first it is not clear if Tong feels the same way; part one details their romance gradually revealing that Tong is also attracted to Keng who is very open about his feelings. We follow the couple as they enjoy long walks, take Tong's sick dog to the vet, shoot pool, and attend the movies. Weerasethakul playfully points to the ironies of Thai culture, which have emerged as a result of its encounter with Western modernity. In one scene the statue of Buddha is accompanied by Christmas tunes. The couple also visits an underground temple set in a cave with a woman who tells them that love is like malaria, the deadly fever of tropical zones. Here Keng is overcome with a panic attack and refuses to travel further into the dark tunnels of the cave temple. The rather slight and less manly Keng, who is not at all afraid, comforts him.

The film lovingly documents the little details of their courtship - Keng place his hand on Tong's knee in a cinema, rests his head on Tong's lap as they sit on a jetty beside a river, leaves a love-note in his pocket. Physically Keng is bigger and appears more in command, more sophisticated and worldly. Yet it also seems clear that Tong wants to be wooed and wants Keng to fall under his spell, to fall into a swoon with love for Tong. Perhaps this offers another meaning of "tropical malady"- the idea of falling in love, to enter a delirious state, to become sick with desire. There is a particularly delightful moment when the two men go to an outdoor concert. The female singer dedicates a song to "Keng of the Forest Patrol" and Tong then joins her on stage in the duet to Keng. The unfolding romance is delightful to watch - sensual, textured, and delicate. Then just as it appears as if Tong is about to respond to Keng with passion he inexplicably walks away, his figure swallowed up by the night. The screen becomes black and it almost appears as if the projector has broken down. The familiar has been rendered strangely unfamiliar.

The second section is entitled “A Spirit's Path”. Keng sits on Tong's bed looking at a photo. The film begins to flicker as a drawing of a tiger fills the screen. An unknown narrator begins to tell the story of a shape-shifting shaman whose soul lives in a tiger that haunts the jungle. The actors who played Keng and Tong play the characters in part two offering another uncanny slippage between the familiar and unfamiliar. Keng is a soldier searching for his companion in the forest and Tong is the shape-shifting shaman, both human and animal. The atmosphere and mood is totally different. The jungle it is so dark, it is difficult to pick out shapes and as the soldier enters further into the jungle everything seems uncanny and surreal - a baboon talks to him, the ghost of a cow walks out of its body, and a tiger appears in a tree. The tiger-spirit appears to be fascinated by 
the soldier's walkie-talkie whose noises see to fill the night air with a kind of spirit talk. Terrified the soldier gradually enters into the forest's heart of darkness. In one scene we watch a naked Tong on all fours crawling through the jungle (recalling the naked figure of the film's opening scene) and at other times he shifts between human and animal. In another sequence he attacks Keng, snarling and hurling him into a ravine.

Roger Clarke points out that few directors have every focused on the forest floor with such detail - "its paw-prints, twigs, dead leaves, snail shells, fly-blown turds, leeches and most of all mud." (Clarke 2) He argues that Weerasethakul has structured this narrative of "bestial strangeness" in two sections so that one will comment on the other.

...the entwined hands, the flowery protestations of love, the sentimental songs on stage, the accepting family members - which Weerasethakul is setting up to derail with his later blast of rotting jungle matter, rutting animal desires, transmigrating sex and death. (Clarke 2)

This is no longer a daytime love story or soap opera, Clarke argues, but the primitive, strange "world of Joseph Beuys and William Blake", artists who explored the shamanistic world of the human/animal in their own work. Tropical Malady's narrative of love between the two men cannot be reduced to a simple story of sexual repression, desire and death. Weerasethakul's deliberate staging of a mix of styles, his barely visible night times scenes, and his reference to shamanism and the spirit world - all of these suggest he is primarily interested in posing questions about what it means to be human.

Gradually the soldier begins to understand the words of the baboon in the trees: "The tiger trails you like a shadow/ his spirit is starving and lonesome/I see you are his prey and his companion". An uncanny beast of the forest, the tiger is both familiar and unfamiliar, lover and killer. The tiger is a manifestation of the two main figures of the film's second part - man and beast. It is also the trapped spirit of the shape-shifting Shaman. Weerasethakul's film effectively undermines the boundaries between human and animal, abolishing the human subject as origin of the text. As in the films discussed, the blurring of boundaries is accompanied by a loss of vision; it is impossible to see anything clearly in Weerasethakul's tropical jungle. Human and animals share the same body and the same emotions. Films from the early period of the cinema, shaped the themes of the Tropical imaginary from a post-Darwinian evolutionary perspective. Weerasethakul however has taken this project further though his exploration of the relationship between human and animal in the context of the soul or spirit which he sees as shared by both man and beast in the interlaced community of forms which make up the tropical imaginary. 


\section{WORKS CITED}

Beer, Gillian. Darwin's Plots: Evolutionary Narrative in Darwin, George Eliot and Nineteenth-Century Fiction. United Kingdom: Cambridge University Press, 2003.

Clarke, Roger. “Tropical Malady.” Sight and Sound. 3 (2005): 1-2.

Creed, Barbara. Darwin's Screens: Evolutionary Aesthetics: Time and Sexual Display in the Cinema. Melbourne: Melbourne University Press, 2009.

Darwin, Francis. The Life and Letter of Charles Darwin, The Echo Library, Middlesex, 2007, vol 1, p. 144 www.echo-library.com

Darwin, Charles. The Expression of the Emotions in Man and Animals, $3^{\text {rd }}$ edn, London: Fontana Press, 1999.

Darwin, Charles. The Origin of Species and the Voyage of the Beagle. New York: Alfred A Knopf, 2003.

Driver, Felix and Martins, Lucina. Tropical Visions in an Age of Empire. Chicago and London, The University of Chicago Press, 2005.

Ekman, Paul. "Introduction to the Third Edition”, in Darwin, Charles. The Expression of the Emotions in Man and Animals, $3^{\text {rd }}$ edn, London: Fontana Press, 1999.

Ferry, Jean. “Concerning King Kong.” The Shadow and Its Shadow: Surrealist Writings on Cinema, ed. Paul Hammond. London: BFI Publishing (1978): 105 -108.

Freud, Sigmund. “The Uncanny”, Pelican Freud Library, vol. 14 Ringwood: Penguin, 1975.

Hogan David J. Dark Romance: Sexuality in the Horror Film. London: McFarland \& Company, 1986.

Jackson, Rosemary. Fantasy: The Literature of Subversion, London: Methuen and New York, 1981.

Melville, Herman, Moby Dick or the White Whale, Boston: The St. Botolph Society, 1922, Google eBook.

Norris, Margot. Beasts of the Modern Imagination: Darwin, Nietzsche, Kafka, Ernst, and Lawrence. Baltimore and London: The Johns Hopkins University Press, 1985.

Stevenson, Robert Louis. The Strange Case of Dr Jekyll and Mr Hyde ed. Martin A Danahay, Peterborough, Ontario: Broadview Editions, 2005.

Wells, H G. The Island of Doctor Moreau. Ed., Brian Aldiss, London: Everyman, 1993. 